\title{
Things Fall Apart and Chinua Achebe's Postcolonial Discourse
}

\author{
Ali Salami ${ }^{1 *}$, Bamshad Hekmatshoar Tabari ${ }^{2}$ \\ ${ }^{1,2}$ University of Tehran, Iran
}

*Corresponding Author: Ali Salami, University of Tehran, Iran

\begin{abstract}
Chinua Achebe, the contemporary Nigerian novelist, is considered as one of the prominent figures in African anti-colonial literature. What makes his works specific is the way he approaches the issues of colonization of Africa in an objective manner and through an innovative language which aims at providing a pathology; a pathological reading meant to draw on the pre-colonial and colonial history without any presumptions so as to present the readers with possible alternative African discourses in future. His first novel Things Fall Apart can be taken as the best representative of such a penchant in Achebe. The present study seeks to approach Things Fall apart by reflecting on those discursive features which have provided the ground for constructing such a pathological reading and an alternative to the colonial discourse. To this end, some key terms introduced by Homi Bhabha and Mikhail Bakhtin such as 'hybridity', 'otherness' and 'polyphony', constitute the cornerstone of this study. Presumably, such an innovative reading of Achebe's Things Fall Apart is to lead to a better understanding of his discourse and the efforts made by him to help the African readers figure out how to piece together what once fell apart; what they can rely on for building an independent future in the so-called postcolonial era.
\end{abstract}

Keywords: Hybridity, Otherness, Polyphony, Voice, Colonial Discourse

\section{INTRODUCTION}

Since its first publication in 1958, Chinua Achebe's Things Fall Apart has caught the attention of such a wide range of African as well as non-African readers that it is no exaggeration in saying that this novel be counted as one of the most outstanding works of literature in modern time. The fact that about six decades after its birth, this novel has sold about twenty million copies around the world and has been translated into nearly sixty languages testifies to its significance and place in the canon of world's modern literature. As a matter of fact, Things Fall Apart may provide a proper space to probe the prevalent features of Achebe's anti-colonial discourse and what has turned out to be known as "Achebeism" in African Literature (Egejuru 24). Such a success can be conceived as the outcome of Achebe's grasping of a proper language: a language capable of representing at its best the Nigerian life and better to omit quest for identity in the precolonial, colonial and postcolonial phases as well as highlighting the effects of the changes which have taken place in different junctures of time in Nigeria.

Given the significance of Things Fall Apart as well as the wide range of ideas offered in the critical readings of this novel, the present study attempts to expand the boundaries of criticism produced by Achebe's first novel by approaching it from a different perspective. What we do here can be seen as an effort to study the major features of Achebe's language and discourse which can be well defined largely by relying on some theories of Homi Bhabha and Mikhail Bakhtin.

\subsection{Theoretical Assumptions}

Homi K. Bhabha is a prominent contemporary literary critic who has contributed generously to postcolonial studies. Bhabha approaches the colonial and postcolonial phenomena from a new perspective due to his double emphasis on the necessity of paying attention to cultural factors and taking them as leading forces in the development of postcolonial studies. Otherwise stated, what Bhabha conceives of postcolonialism is its near affinity to cultural studies on the basis of postmodernist assumptions. That is why he emphasizes the importance of avoiding overgeneralization or objectification of theory on account of the unique nature of each colonial context. He maintains that a critic should thoroughly investigate a various number of cultural dialectics which lead to the 
formation of the related context. Thus, for him, linguistic discourse turns out to be the complex mechanism representing the greater interrelated body of socio-political discourses and ruling forces or power relations at work controlling the formation of meaning, identity and reality on different levels through different ideological tools. In plain terms, Bhabha focuses on the language produced by the colonizer in the colonial era which he assumes to be discursive tools in the hands of the colonizers so as to grasp their colonizing intentions. So, he concentrates on postcolonialism and the formative phases of such a new discourse in the existing "liminal space" (50) or a location in which a complex series of varied cultural interactions rather than a bundle of straightforward dialectics between the colonizer and colonized can occur to produce meaning (Chakraborty 1).

According to Bhabha, such a cultural liminal space is the formative outcome of "hybrid identities", through a complex process named "translation" (Rutherford 210) - as introduced earlier by Benjamin; a process in which a series of signs or symbols are replaced with new sets all standing in a relational position with the discursive controlling force. This opinion by Bhabha springs from his application of "Derridean difference", (Xie 155) to postcolonial studies and additionally the assumption that the existing indeterminacy arising from the complex process of linguistic signification in the liminal space of cultural translation results in the indeterminacy of colonial discourse which ultimately leads to the denial of the fact that culture and identity are of a holistic nature or organic unity. In Bhabha's point of view, in order to study a postcolonial subject, a critic is faced with hybrid identities and should accord attention to the existing identity "multi- positionality" within the space of discourse and how through difference or differentiation from the 'other', a subject is to be identified (156) from the colonizer.

On the strength of the current assertions, it can be deduced that Bhabha's postcolonial reading is an attempt to carry out two tasks simultaneously: studying how a colonized subject is to come up with 'otherness' and 'hybridity'or how identity crisis in engendered by the colonizer through different discursive mechanisms of colonization and how one can choose a better dialectical position within a discourse so as to reflect on what has affected his identity hybridity.

In fact, Bhabha's postcolonialism is indebted to Bakhtin's emphasis on the importance of paying attention to the "sociohistorical context"(Hoy 765)in which a literary work is produced. Additionally some notions introduced by Bakhtin in defining the nature of the discourse in a novel seems to be relevant to the present study inter alia 'Polyphony', 'dialogic', 'heterologgolssia', and 'carnivalesque'.

It seems necessary to consider the context upon which Bakhtin's philosophy and theory are built. Even though he lived in the age of the Soviet socio-political power, one cannot claim Bakhtin is a blind follower of Marxist ideology which had a propensity to function as a grand narrative eradicating all other minor ones. Actually, Bakhtin is a meticulous observer and can never deny the power of ideology. So, in developing his theories, he speaks of the power of ideology and how it may affect the context of the formation of meaning at different levels. To be precise, Bakhtin is against ideological monophony and what may arise out of radicalism, as such a condition tends to avoid the chances for developing a body of social dialogues and active voices in different acts of social dialogues which are the prerequisite for constructing valid and healthy social discourses. 'Polyphony' is the term he attributes to this reality about discourse and considers novel as the proper literary genre which in its ideal form should reflect such a reality about the dialogic nature of discourse through linguistic properties. Bakhtin adds that in an ideal novel which has a proper language of non-abstract nature and reflects characters' active engagement "with the world and with each other" in a proper context (Sandler 156), a critic can witness a vivid distance put between the authorial voice and those belonging to the others as the discursive authenticity of each voice and the identity thrust upon each one in the course of the novel must mirror a kind of "existential self-positioning" ( Pechey 27) at work in such a context. Besides, he asserts that each voice's existence and its epistemological vitality reflected within the framework of a novel should attack probability of the emergence or occurrence of "pedagogical dialogue" where the voice of the knowledge comes only from the author and "confronts ignorance unilaterally and unequally" (Bakhtin, Problems 81).

Bakhtin also speaks of another important discursive quality in a 'polyphonic' novel known as "carnivalesque". He maintains that in the same way a carnival in its medieval sense "brings together, unifies, weds, and combines the sacred with the profane, the lofty with the low, the great with the 
insignificant, and the wise with the stupid"(123), a novel possessing the carnivalesque quality can bring into expose "the latent sides of human nature" (Gardiner 46), as the dominant or official voice may continually avoid polyphony. Thus it is only through an act of dialogization or blending the excluded history and carnivalesque with the official discourse in a single text and putting them into juxtaposition and negotiation that a true and authentic discourse is born (Will 132). This form of philosophizing consequently defines Bakhtin's understanding of reality. As Garima Aggarwal asserts "in Bakhtin's point of view, truth is not singular, linear and universal" and that it has "the responsibility of becoming a multifaceted phenomenon, reflecting the variety of voices in society" (91).

Given Bakhtin's perception of the nature of 'truth', it is not unlikely to infer why he thinks a novelist should provide a proper context for all voices to be heard. However, Bakhtin envisages a precondition in the context of a novel which is the novelist's ability to depict the existential efforts of each voice so as to make sense of the probability of the existence of other 'constitutionalizing' (Gardiner71) voices. Indeed, not only the novelist should reflect a picture of what is at run among different voices, but also he must picture what is going on inside each voice as well as the circumstances under which they are to be mingled or exposed. Thus, a novel is a space where the novelist is to portray how the hybridity of voice is engendered.

As stated earlier what is of paramount significance is to make sense of the circumstances under which the novelist has managed to provide an alternative discourse in order to attack the discursive dominance of the British colonizers in his Things Fall Apart. Putting this novel in center and reading it in sequence based on the theories of Bhabha and Bakhtin, the major task of the present study is to expand the realms of perception about the novelist and how he has framed his specific discourse.

\section{DISCUSSION}

The most salient feature of a discourse, whether oral or written, is undoubtedly the linguistic and grammatical specifications of the language in which it is produced. Sequentially, the key role of language for the production of a national literature and identity can by no means be denied. That is why, in the 1950s and 1960s when the African movements for independence were reaching their climax, the issue of a proper African written language gained double significance to fill in the gap; a gap caused by the lack of ample written literature or literary history due to the fact that the African oral literature had traditionally moved in a very different direction from what was considered the main stream of modern literature in Europe. Actually, that condition was the result of imposing non-African criteria of criticism on the oral background of Africa by those who had not a clear understanding of the African pre-colonial literary background. It is not then hard to infer why Achebe's main endeavor was to show through his writings the necessity of seeking a proper language for African literature and criticism with a capacity to bring insight both to non-African and African readers, writers and critics.

Achebe's success in the case of a proper language lies in his clear understanding of the nature of African (Nigerian) oral traditions and their capacities as well as the disjunction imposed by the clash between the pre-colonial traditions and the modernity of the civilization promoted by the white new comers and that which had brought about a kind of oblivion for the Africans living in the regions previously located in the mainstream of the oral African literature. Notably, Achebe was one of the first Nigerian literary figures who found the necessity of educating the African readers by making them aware of the truth that "their past with all its imperfections was not one long night of savagery from which the first Europeans, acting on God's behalf, delivered them" (Novelist, 45). That is why Achebe regards a novelist as a teacher who is tasked with providing the readers with an alternative discourse based on a proper language.

The specific language crafted by Achebe in his first novel, Things Fall Apart, was in fact successful to the extent that it put an end to a great body of controversial debates about the proper language for African writing since some critics like Wali and Ngugi had tried to show the urgency of throwing away the language of the colonizers and relying on ethnic languages as the medium for the production of African literature. What Achebe asserts in an article titled "The African Writer and the English Language", can be taken as the best proof to discredit those critics' propositions in the case of abandoning European languages. Achebe differentiates between the 'ethnic' and 'national' literature and introduces the use of English as a unifying discursive tool because it can become a device to bring together the oral literary potential of Africa and transfer it in a united written language that is not 
limited to a province and "has a realized or potential audience throughout [the country's] territory" (56). Therefore, it can be said Achebe's suggestion for using English shows that he is a more conscious figure than other critics of the age in making sense of the realities of the colonial history in Nigeria and other parts of Africa. At this point this question may arise: If Achebe is in favor of adopting English for producing African national literature, what kind of English is it? Another way, it must be reciprocally asked: why does the English used by Achebe catch the attention of many readers of Things Fall Apart and is taken by majority as the first example of Nigerian anti-colonial literature? To answer this question, it must be investigated how Achebe tries to give shape to his discourse in Things Fall Apart by relying on the language of the colonial center.

One of the strong points in Achebe's strategy in taking advantage of English in his novel is explained by Carey Snyder who asserts Achebe " indigenizes the English language, reproducing attributes of African oral tradition" (162). As a matter of fact, Achebe, despite his emphasis on using English, is in stark contrast with the "ethnographical" quality of the literature produced by the white colonizers about Nigeria and Nigerian people (154). Thus, Achebe endeavors to take up the format as a means of deconstruction and the specific version of English language used by him in a novel like Things Fall Apart is a critique of the dehumanizing "narratives of colonialist writers" who tried to show Africa had no history and was primitive (Osei-Nyame 149).

The first characteristic in the case of Chinua Achebe's language is the notion of 'historicity'. Actually, for Achebe a depiction of a humanized version of Africa and its people through his language is of paramount significance since the Western ethnographical tradition, as old as the Greek and Romans ethnographical records, had a certain set of fixed beliefs about Africa and as a result, stock images about Africa were formed. For example, the idea of dealing with the strange and the unknown with an objective point of view was among the central assumptions of this form of writing. Precisely, the Western ethnographical writer had the presupposition that he was going to face an 'other' which needed to be recorded in full details from a disinterested standpoint. Thus, the idea of confronting 'the other' or what was strange and hard to infer based on the western logic or mentality had created a distance in between and caused the producers of such texts to remain at the surface level and get content with objective and realist record of physical details without making any efforts to provide a psychological or philosophical reinterpretation of the new phenomena. What Achebe decided to do was to respond to this form of writing and what had actually turned out to act as a strong 'otherizing' device in the hands of the British Colonizers by giving birth to a kind of novel which can be called the 'ethnographic novel'. In this regard, Elizabeth Ferna describes it as a kind of novel "written by an artist from within the culture which presents an authentic representation of that culture" (q.t.d. in Snyder 157).

Applying Ferna's definition of 'ethnographic novel' to Things Fall Apart, a critic can perceive why Achebe makes all efforts to act as an insider with objective point of view and allocates about one hundred and forty pages to provide a full record of the communal life of Igbo people before the arrival of the colonial forces and how such a situation acted as a running force facilitating the downfall of the protagonist of the novel, Okonkwo, who is depicted by all "his human weaknesses and strengths" so as to authenticate the fact that like other human beings, Igbo person or individuality " is conceived as the primary agent of change in society and the controller of both his and society's destiny" (40). The effect of such a depiction is in truth enhanced by the ironic terminal parts of the last chapter when the 'district commissioner', unable to understand the motifs beyond Okonkwo's act of suicide approaches the matter like a Western traditional ethnographer and finds the issue of suicide "some new material" (Trilogy 145), for a "whole chapter" or a "reasonable paragraph" after "cutting out details" for his book to be titled "The Pacification of the Primitive Tribes of the Lower Niger" (146).

One of the striking discursive features of Things Fall Apart originates from the artistic use of the Igbo proverbs through an act of literal translation and without deviating from the Standard English. As a matter of fact, it is the result of the meticulous syntactic adjustments and vocabulary selectiveness that despite their estrangement those proverbs appear to be quite meaningful and by consequence easily perceived even by the non-Igbo English readers of the novel having little or no knowledge of the Igbo culture and its linguistic properties. Therefore, proverbs can be considered discursive devices in the hands of Achebe to make for "illusion of cultural proximity" so as to deal with the non-Igbo readers' presumptions about the "otherness" of the culture they confront through pages of the novel (Irele 123). These proverbs should also be considered as means which make it possible to express and 
illustrate ideas vividly (Alimi 124); thus their inclusion in the novel by Achebe must have been one of the main reasons why he has succeeded in drawing on cultural realities and the epistemology of Igbo people. Additionally, it can be suggested that such recurrent use of proverbs is somehow a kind of revitalization and aims at reminding the value of their culture and language to all Igbo communities who had lost their belief in the powerful essence of their mother tongue and the native culture after decades of the hegemonic presence of the language of the colonizers in their society. Hence, it is not hard to conjecture why Achebe foreshadows the centrality and the thematic significance of the Igbo proverbs - as a powerful discursive and rhetorical device - at the beginning of the novel in the episode dealing with the story of Unoka, Oknokow's father, to Okoye: "Among the Igbo the art of conversation is regarded very highly and proverbs are the palm-oil with which words are eaten" (Trilogy 7).

Another instance of drawing on the issue of the significance of language can be found in the chapter sixteen of Things Fall Apart which focuses on the way the white Christian preachers speak to people of Umuofia. Actually, the presence of a black interpreter talking in Igbo to the people of Umuofianonfluently and through wrong words is symbolic. At first glance, the reader may take the black people's act of laughing at the interpreter as a simple joke, but by delving into the issue, he may find out that it represents the lack of a true negotiation between the white men and the Igbo people or the lack of mutual understanding because the words conveyed through the language of the interpreter are references to referents as if from void and of no place in the lingual cosmology of the Igbo people. Achebe again highlights the fact that for the people of Umuofia the white man was also an 'other', who had "iron horses" (Trilogy 102), and was "mad" (103) by speaking of strange religious beliefs.

There are also other instances in the novel which can prove that language turns out to be a very significant theme for Achebe: Early in the novel, in chapter three, the reader finds out how in precolonial Igbo community a constructive social contract could be framed based on some conversional or dialogic norms and social customs without creating any uproar or threat to the stability of the Igbo society. The episode tells how Okonkwo was able to convince Nwakibie to give him enough yams for share-cropping due to his awareness of the Igbo culture and language since he takes kola seeds and wine with him as gifts to Nwakibie and starts the conversation based on the social norms of respect and politeness through a famous Igbo saying: "A man who pays respect to the great paves the way for his greatness". (Trilogy 16). Such an instance and other similar ones - like the court scene in the tenth chapter reflecting the perfect judiciary system and language of Umuofia - gains double significance when compared to the attempts made in the final pages of the novel; futile attempts made by the titled men of Umuofia in order "to open a respectful dialogue" with the district commissioner about what happened to the church. (Morrison 87). They do their best to negotiate through their art of conversation but the district commissioner tricks them and sends them to prison.

In the same manner as proverbs, folklore stories incorporated by Achebe into the novel are very significant discursive elements in developing an alternative discourse to that of the colonizer. According to Shuchi Agrawal, along with proverbs, "stories are the staple of African society", and making use of the stories within the space of a novel is one of the important factors which aid Achebe to picture the Igbo internal values and moralities in an objective manner and without "opposition to European culture" (123). Actually, the whole novel is constructed in the form of a comprehensive Igbo tale and it can be postulated that Achebe's reliance on "simple mode of narration and equally simple prose style" in Things Fall Apart is quite intentional and done to foreground the traditional Igbo storytelling techniques (q.d.t in Medansky 97). In addition, stories included by Achebe in his novel are important discursive tools in developing the thematic significance of the novel. For example, the story of tortoise in the eleventh chapter deals with the power of language and how one can convince other people. At the same time, this story can be taken as the story of how one's "rise and fall" (Roscoe 121) may be dependent on his words, language and participation within a social dialogue. Another major story which plays a great role in the development of the thematic significance of the novel is the story of 'mother kite and her daughter' narrated by Uchendu, Okonkwo's uncle. As a matter of fact, the story is narrated in order to comment on the mistake committed by the people of 'Mbaino': killing a white man who would say nothing and would not show any harsh reactions against the black people gathering around him. So this story indicates the fact that those who remain silent and think more must be feared, not those who just prattle and do nothing. Accordingly, it can be assumed that such a narration is to foreshadow the complex politics of the white colonizers and how they tended to act in indirect ways so as to spread their hegemony. 
Besides relying on Igbo proverbs, idioms and stories, Achebe makes use of another technique to enhance the postcolonial features of his discourse. This strategy which is more straightforward than those other ones discussed above can be called hybridization through transliteration. Definitely, Achebe has inserted a series of Igbo words into the English text of the novel at some points; words left to be inferred in the context while in numerous other zones lucid English referents are used to point to Igbo references based on a kind of semantic transition or translation. He must have had some ulterior motives. Actually, most of these transliterated words, appearing in italic form, are related to cultural, religious and social specifications of the people of Umuofia and they can be considered linguistic devices adopted by the novelist in order to gain a kind of localization within a discourse framed on the basis of a foreign language. For example in the chapter ten which provides a clear picture of the efficient judiciary system in Umuofia, the reader finds people answering to egwugwu, or the masked men representing the spirits of the ancestors of the village, in Igbo language:

'Umuofia Kwenu!'

'Yaa!'

'Umuofia Kwenu!'

'Yaa!'(Trilogy 63)

The effect of such a technique on the readers will be more tangible when the court scene, as one of the manifestations of the self-sufficient pre-colonial Umuofia, is compared to another social scene in the seventh chapter which revolves around the story of a wrestling match. There unlike the court scene chapter the readers find the poem in praise of the winner in pure English:

Who will wrestle for our village?

Okafo will wrestle for our village

Has he thrown a hundred men?

He has thrown four hundred men?

Has he thrown a hundred Cats?

He has thrown four hundred Cats.

Then send him word to fight for us.

(Trilogy 38)

Based on the two examples, it can be inferred that since the issue of judging in court through the spirit of the ancestors is so unique and of the cultural specification of Umuofia, Achebe needs to highlight it more than a wrestling scene, that may be found in many other cultures too. Thus, he uses Igbo language to draw on the matter of egwugwu while in the wrestling match scene, even the final laudatory poem is presented in English translation. Respectively, it must be stated that by such an act of foregrounding in chapter eleven about egwugwu, Achebe is somehow addressing the native readers of the novel and reminding them not to forget one of the most powerful pre-colonial social systems of Umuofia: that their society in pre-colonial age could practice justice through an efficient system while the court brought later by the whites had caused many problems, for example in the case of landowning. Precisely, Achebe criticizes the colonizers' idea that "England's most valuable contributions to its colonies" was "promising to institute a legacy of reason and tolerance in a context that the British saw as utterly chaotic" (Reichman 55).

Thus, it can be asserted that he has tried his best to provide a discourse capable of portraying the positive aspects of hybridity, alongside with its negative repercussions which is tantamount to providing an alternative to the colonial text or any other pieces of writing which may find hybridity against homogeneity of language and a sign of giving chance for self-expression to the undecipherable 'other'. However, it seems that studying Achebe's discourse in Things Fall Apart as an alternative to the colonial discourse and a model for Nigerian national literature acquires much more concentration by going beyond its language.

To this end, we should investigate the thematic and ideological issues conditioning Achebe's discourse and its linguistic features. This can be possible when according Bhabha, the ontological and existential processes at work within each voice and between different voices in the novel are put into 
study. To be precise, it should be analyzed how Achebe has been successful in crafting a 'heteroglossia', complying with Bakhtin's theories, to show the way different Igbo voices with all their complexities and those of the white men come into contact with each other. Furthermore, it should be detected how those negotiations or struggles made by Igbo men in the way of 'existential self-positioning' in the colonial context are formed and delineated by the voice of the narrator.

Focusing on the text of the novel shows the fact that the voice which is heard more than the other voices within Things Fall Apart is the voice of Okonkwo. Actually, the thematic significances of all voices heard within that discourse is revealed when defined in the way they enter a dialogic relation with Okonkwo's voice or conditioned through the voice of the narrator for or against Okonkwo's voice. No doubt, the voices heard in Things Fall Apart can be classified into five main categories: Okonkwo's voices, the communal voice of Igbo society, the voice of $O s u$, the voice of the narrator, and the voice of the British colonizers. However, it must not be ignored that each category itself consists of several constituents and this in reality originates from the subtlety of the 'voice' reflected by the theory of 'polyphony' in novel espoused by Bakhtin which deals in depth with how hybridity is born in a dialogue.

As it was just mentioned the voice of Okonkwo, the protagonist, is dominant within Things Fall Apart. Numerous studies have viewed Okonkwo as a universal tragic hero and focused on his story as the story of the downfall or shattering of old values and traditions by the arrival of the new value systems. Nevertheless, most of these studies have vastly ignored the fact that the generic classifications are the product of complying with Eurocentric criteria; thus they are incapable of relating to what happens to a character like Okonkwo in an African context in order to provide a comprehensive analysis even though the presence of such tragic elements in Things Fall Apart are undeniable. Therefore, by putting aside the limitations imposed by a Eurocentric reading of the Okonkwo as a mere Aristotelian tragic hero, one should try to reach a more comprehensive view of story of his downfall and this can become possible through analyzing what is conveyed by his voice.

Early in the novel it is revealed through the narrative voice that Okonkwo hated his father Unoka, since when he died "he had taken no title at all and was heavily in debt" (Trilogy 8). It is not hard to guess that possessing enough prosperity to grasp titles in the patriarchal society of Umuofia was one of the few channels through which a man like Okonkwo could fulfill his desire for self-actualization or stabilizing his voice within the social discourse. Actually, a kind of inferiority complex is developed in Okonkwo due to his father's social position and this functions as the very psychological factor engendering Okonkwo's hatred toward what the society would define or label as feminine. Similarly, the matter justifies why Okonkwo's "rigid conception of masculinity and gender roles" is always dictated on his son Nwoye and his "putative effeminacy" (164). Such an attitude in Okonkwo may be seen as the reason beyond his tendency toward repressing internal "feminine principles", or voices while unlike its patriarchal nature the Igbo society expected its members to create a balance between male and female principles within themselves (Shea 76). Unable to do so, Okonkwo is then depicted as one who cannot control his wrath in beating one of his wives even during the week of peace, thus committing a sin against the goddess of earth. Additionally, his fear to lose his status in the society or appearing as a weak character makes him ignore the wise advices of Ezedu and Obrieka not to take part in the matter of a sacrifice (Iyasere 68), determined by the oracle: the sacrifice of Ikemefuna, the boy brought up in his clan like his son calling him father. From another perspective, what brings about Okonkwo's downfall at the end is his inability to come up with the internal contradictory voices in order to grasp a valid understanding of the truth and how he must move toward grasping self-actualization. That is why he cannot think like his friend Obrieka about the changes happening in his society by the arrival of the colonizers and finds them as threats to the loss of his voice within the body of social discourse.

However, going beyond the surface level and taking into consideration the narrative voice, a reader may find out that the centrality of Okonkwo's voice should not be regarded as the fact that the whole novel is working to reflect on that end. Precisely, Achebe is not limiting himself to the portrayal of the tragic downfall of an individual named Okonkwo in Aristotelian terms and intends to surpass the level of individuality so as to be in concord with the communal nature of the Igbo pre-colonial society through an omniscient or objective narrative. In other words, if a tragic African story must be told it must be the tragedy of a communal downfall; the downfall of the majority of Igbo people who were not able to avoid the repression of their voices by the powerful colonial voice and "the harsh 
imposition of unbending westernization" resulting in loss of their "original value system" in consequence (Ogude 116). If Okonkwo is a tragic hero, his hamartia is his inability to comprehend the new emerging social discourse and how he can establish a stable position for himself through his true voice. Choosing the wrong way, he commits suicide which is an unforgivable sin in his religion. However focusing on him and his shortcomings, a reader should not forget that the true tragedy was in fact brought about by "colonial intolerance" (Levine 96) leaving no room for Igbo voices to be expressed.

The next point is the communal voice of Igbo society. As stated earlier, Achebe's aim is to highlight the Igbo pre-colonial life and to provide a comprehensive record of it in an objective manner in order to help his people revive national identity which he presumes to functions as a prerequisite for independence struggles. In fact, the Igbo pre-colonial identity was extensively dependent on community members and the vitality of the social discourse was the result of a room provided for each voice to be expressed though conditioned by religious, social and judicial roles. Thus, Achebe's discourse in Things Fall Apart needed to sketch those realities about the communal voice of Igbo society and it can be claimed he has fulfilled the task in the best way by relying on some ritualistic aspects of their culture which is quite metaphoric: egwugwu or as the glossary part at the end of the novel defines "a masquerader who impersonates one of the ancestral spirits of the village" (Trilogy 147). Going through the novel the reader will get to know the symbolic significance of the voice of egwugwu as it is a cardinal sin to unmask one or to associate that voice with an earthy individual from the titled men of the village wearing the mask. By analogy, this is the communal voice of the ancestors rather than the masked titled individual who witness rituals, consult meetings or even court scenes through his knowledge of religious and social rules. Achebe draws on the matter very artistically in chapter thirteen of the novel dealing with a judgment case. Appropriately, it will be vivid why Achebe later in the third part of the chapter magnifies the act of unmasking of a agwugwu by a new Christian Igbo since this act can be taken symbolically as a facilitator of falling apart of the Igbo pre-colonial communal values: what could unify them was their history, ideology and heritages; all condensed in one voice in a process somehow close to transubstantiation in Christianity.

The next category to elaborate on with regard to the polyphony of voices heard in Things Fall Apart, is the voice of $O s u$ or the outcast: one who was dedicated to a god and not allowed to negotiate or mix with the rest of the community or the freeborn in any event (Trilogy 148). As Sara Talis O'Brien states the notion of $\mathrm{Osu}$ is a contradiction to the Igbo ideology and how dynamically it would provide through the system of gaining titles "right to climb up to the top of Igbo society" (92). To this exception one must add the matter of the twin babies left at the evil forest to die because "the Earth had decreed that they were an offence on the land and must be destroyed" (Trilogy 87). Achebe's concentration on the matter of $O s u$ or from another standpoint, the 'other' inside Igbo society in the first part of the novel is very meaningful and justifies what is going to happen for these outcasts with the arrival of the white colonizers. This is to reinforce Achebe's attempt to provide a pathological reading of why things fell apart which is aimed at an objective portrayal to the extent that it cannot refrain from reflecting voices historically repressed by the Igbo society itself. It is then necessary to seek how the voice of the narrator is at work.

Many readers have noticed the important role the voice of the narrator plays in Things Fall Apart and have proposed different and sometimes contradictory ideas about its mechanism. However, it can be asserted the narrative voice in this novel is very significant as it is to enhance the 'polyphonic' features intended by Achebe through adopting different narrative positions in the course of the novel, breaking the boundary between omniscient and non-omniscient which in consequence leads to a better view of the precolonial Igbo voices actively taking part in various acts of the social discourse plus their encounter with the voices of the new white comers and the new emerging discourse.

The discussion about the issue of voices in Things Fall Apart will not be complete if the voice of the colonizers is excluded. In fact, Achebe intends to provide the reader with a space where all voices can be heard free from any bias or presumptions. Thus he highlights the importance of foregrounding the matter of variety as well as hybridity of voices and how by adopting new positions at different points within an act of discourse each voice is to synthesize a different effect. In this sense, Achebe's main task as a postcolonial novelist can be taken to show how the voice of the white newcomers imposed new discursive roles on the Igbo voices and conditioned them so as to grasp hegemony. However, the reader must not forget that Achebe is also successful in depicting an alternative or showing the 
possibility of moving toward a new liminal space of negotiation for future which the readers realize after carefully scrutinizing the clash between the voice of the colonizers and the voice of Igbo people or the clash of discourses of different natures. Thus this matter sheds light on the importance of Achebe's careful task of introducing different voices heard within the body of colonial discourse in the third part of Things Fall Apart and their discursive significance: the voice of Church bodies, the voice of British commissioners and the voice of the new converts.

\section{CONCLUSION}

The present study was an effort to examine Things Fall Apart by Chinua Achebe through the filters of Homi Bhabha's postcolonial theories as well as Mikhail Bakhtin's ideas in the case of the nature of polyphonic novel and their relevance to postcolonialism. Based on the discussion held, it can be concluded that Achebe's novel is by and large an attempt to provide a record of what the otherizing polices of the colonizers brought about to the Igbo (Nigerian) people by denying the chance of cultural negotiation and repressing their voices. However, from another perspective the novel is a pathological reading of the past depicted by Achebe in order to reflect how in future the Igbo subjects can move toward decolonization by relying on 'hybridity' as a source of strength which can only be possible with regard to the existing potentials to build strong new voices. In this sense Things Fall Apart can be taken as a postcolonial discourse drawing on the pre-colonial as well as the colonial Nigeria in an objective manner in order to help the Nigerian readers find how to piece together what once fell apart.

\section{REFERENCES}

[1] Achebe, Chinua. The African Trilogy, Things Fall Apart, No Longer at Ease, Arrow of God. Every Man's Library, 2010.

[2] “The Novelist as Teacher." Hopes and Impediments, Selected Essays. Anchor Books 1990.

[3] Alimi, A. S. "A Study of the use of proverbs as a literary device in Achebe's Things Fall Apart and Arrow of God." International Journal of Academic Research in Business and Social Sciences, vol. 2, no. 3, 2012, pp.121 -127.

[4] Agrawal, Shuchi. "A Postcolonial Study of Chinua Achebe's Things Fall Apart." International Research Journal, vol 1, no. 5, 2010, pp. 122-26.

[5] Bhabha, Homi. The Location of Culture. Routledge, 1994.

[6] Bakhtin. Mikhail.Problems of Dostoevsky's Poetics, edited and translated by Caryl Emerson. Manchester UP, 1984.

[7] Chakraborty, Arup Ratan. "Liminality in Post-Colonial Theory: A Journey from Arnold van

[8] Gennep to Homi K. Bhabha."Anudhyan: An International Journal of Social Sciences (AIJSS) vol.1, no.1, 2016, pp.145-153.www.rnlkwc.org/pdf/anudhyan/18_04.../Liminality_in_Post-Colonial_Theory.pdf.

[9] Egejuru, Phanuel. "Traditional Oral Aesthetics in the Modern African Novel: Obinkaram Echewa's The Land's Lord." The Growth of African Literature: Twenty-Five Years After Dakar and Fourah Bay, edited by Edris Makward, Thelma Ravell-Pinto and Aliko Songolo Africa World Press, 1998.

[10] Erkki Peuranen "Bakhtin: Soft and Hard." Dialogues on Bakhtin: Interdisciplinary Readings. edited by Mika Lähteenmäki and Hannele Dufva. University Printing House 1998.

[11] Gardiner, Michael. The Dialogics of Critique M.M. Bakhtin and the Theory of Ideology. Routledge, 1992.

[12] Hoy, Mikita. "Bakhtin and Popular Culture." New Literary History,History, Politics, and Culture, vol. 23, no. 3, 1992, pp.765-782. www.jstor.org/stable/469229.

[13] Irele, F. Abiola. The African Imagination: Literature in Africa and Black Diaspora. Oxford UP, 2001.

[14] Levine, Alan. "Chinua Achebe and the Nature of Social Change." The Moral of the Story: Literature and Public Ethics, edited by Henry T. Edmonson. Lexington Books 2000.

[15] Medansky, David Patrick. Things Fall Apart: Deconstructing the Humanities Cannon. 2011.University of Colorado Boulder, thesis.

[16] Morrison, Jago. Chinua Achebe. Manchester UP, 2014.

[17] Ogude, James. Chinua Achebeís Legacy: Illuminations from Africa. Africa Institute of South Africa, 2015.

[18] Osei-Nyame, Kwadwo. "Chinua Achebe Writing Culture: Representations of Gender and Tradition in Things Fall Apart." Research in African Literatures, vol. 30, no. 2, 1999, pp. 148-64.

[19] Pechey, Graham. Mikhail Bakhtin, the Word in the World. Routledge, 2007.

[20] Reichman, Ravit. "Undignified Details: The Colonial Subject of Law."Bloom's Modern Critical Interpretations, Chinua Achebe's Things Fall Apart, edited by Harold Bloom. Infobase Publishing, 2010. 
[21] Roscoe, Adrian A. Mother is Gold: A Study of West African Literature. Cambridge UP, 1971.

[22] Sandler, Sergeiy. "Language and philosophical anthropology in the work of Mikhail Bakhtin and the Bakhtin Circle." RIFL, vol. 7, no. 2, 2013, pp. 152-165.

[23] Searle, Alisone. "The Role of Mission in Things Fall Apart and Nervous Condition." Literature and Theology, vol. 21, 2007, pp. 49-65.

[24] Shea, George. A Reader's Guide to Chinua Achebe's Things Fall Apart, Multicultural Literature. Enslow Publishers, Inc., 2008.

[25] Snyder, Carey. "The Possibilities and Pitfalls of Ethnographic Readings: Narrative Complexity in Things Fall Apart." College Literature, vol. 35, no. 2, 2008, pp. 154-74. JSTOR, www.jstor.org/stable/25115497.

[26] Wills, Clair. "Upsetting the Public: Carnival, Hysteria and Women's Texts." Bakhtin and Cultural Theory, edited by Ken Hirschkop and David Shepherd, Manchester UP, 2001.

[27] Xie, Shaobo. "Writing on Boundaries: Homi Bhabha's Recent Essays." ARIEL: A Review of International English Literature, vol.2, no. 4, 1996. pp. 155-166.

\section{AUTHORS' BIOGRAPHY}

Ali Salami, PhD. is an Assistant Professor of English literature at the University of Tehran. An internationally published author, Salami has written extensively on gender and discourse, Shakespeare and postcolonial literature.

Bamshad HekmatshoarTabari is a $\mathrm{PhD}$ candidate in English Literature at Alborz Campus, University of Tehran, Iran. He is a lecturer at some English Institutes of Higher Education in Iran. His areas of interest are Postcolonial Studies, Comparative Literature, Language Acquisition and TEFL.

Citation: Ali Salami, Bamshad Hekmatshoar. "Things Joined together for the Reader: Things Fall Apart and Chinua Achebe's Postcolonial Discourse" International Journal on Studies in English Language and Literature (IJSELL), vol 6, no. 3, 2018, pp. 19-28. doi:http://dx.doi.org/10.20431/2347-3134.0603004.

Copyright: () 2018 Authors. This is an open-access article distributed under the terms of the Creative Commons Attribution License, which permits unrestricted use, distribution, and reproduction in any medium, provided the original author and source are credited. 